\title{
PENGARUH KUALITAS LAYANAN TERHADAP KEPUTUSAN NASABAH MENGGUNAKAN JASA BANK TITIL
}

\author{
Oleh: \\ Ahmad Sauqi \\ Program Studi Manajemen \\ Sekolah Tinggi Ilmu Ekonomi Mandala \\ Email : \\ sauqiastie-mandala.ac.id
}

\begin{abstract}
ABSTRAK
Penelitian ini berjudul Pengaruh Kualitas Layanan Terhadap Keputusan Nasabah Menggunakan Jasa Bank Titil Di Kecamatan Sukorambi, penelitian ini bertujuan untuk mengetahui pengaruh secara parsial dan simultan kualitas pelayanan yang terdiri dari Reliability, Responsiveness, Assurance, Emphaty dan Tangibles terhadap keputusan nasabah untuk menggunakan jasa Bank Titil di Kecamatan Sukorambi. Penelitian berjenis Causal Research dengan pendekatan kuantitatif ini dilakukan diwilayah Kecamatan Sukorambi Jember yang meliputi 3 Desa yaitu Desa Sukorambi, Desa Karangpring dan Desa Klungkung. Sampel yang digunakan sejumlah 30 responden.Uji analisis data yang digunakan meliputi uji validitas, reliabilitas, modus, regresi berganda, koefisien determinasi, uji t dan uji $\mathrm{f}$. Hasil penelitian menunjukkan bahwa item kuisioner yang diisi responden adalah valid, nilai cronbach's alpha sebesar 0,746 yang artinya lebih besar dari 0,60 maka daftar pertanyaan yang diuji dalam penelitian ini adalah reliabel. Uji t menunjukkan variabel Tangibles $\left(\mathrm{X}_{1}\right)$ dan Assurance $\left(\mathrm{X}_{4}\right)$ berpengaruh signifikan, variabel Reliability $\left(\mathrm{X}_{2}\right)$, Responsiveness $\left(\mathrm{X}_{3}\right)$, dan Emphaty $\left(\mathrm{X}_{5}\right)$ tidak berpengaruh signifikan. Pada Uji f menunjukkan $\mathrm{f}_{\text {hitung }}>\mathrm{f}_{\text {tabel }}$ yang artinya secara simultan 5 variabel tersebut berpengaruh secara signifikan. Berdasarkan hasil riset dapat disimpulkan bahwa penampilan dan pelayanan yang prima membuat pelanggan tertarik kepada jasa bank titil.
\end{abstract}

Kata Kunci: Kualitas, Layanan, Bank, Titil, Sukorambi

\section{A. PENDAHULUAN}

Negara Indonesia yang terkenal subur dan kaya dengan sumber daya alamnya (SDA) dari sejak awal kemerdekaannya pada tahun 1945 hingga saat ini dimasa pemerintahan Presiden ke 7 sudah mengalami banyak perkembangan yang salah satunya adalah dari sektor perekonomian. Perkembangan perekenomian Negara Indonesia bisa dilihat dari pemerataan perekonomian itu sendiri yang sudah mencapai hampir seluruh pelosok tanah air, kemudahan baik dari sisi sarana dan prasarana yang sudah kita nikmati saat ini merupakan bagian dari adanya perkembangan perekonomian bangsa yang semakin maju. Sektor perekonomian yang sangat cepat berkembang ini tentunya didukung oleh kebijakan-kebijakan 
pemerintah Indonesia yang selalu mendorong percepatan dalam mencapai tujuan luhur mensejahterakan seluruh rakyat Indonesia. Salah satu kebijakan pemerintah adalah dengan menurunkan suku bunga bank, kebijakan ini diharapkan mampu semakin meningkatkan perekonomian bangsa karena adanya gairah baru dari pelaku bisnis yang mendapatkan angin segar atas penurunan suku bunga pinjaman di perbankan. Bank konvensional yang ada di Indonesia bisa dikatakan cukup banyak mulai dari BRI, BNI, BCA, Danamon, Mandiri dan lain sebagainya. Sebagai gambaran dapat kami sajikan suku bunga dasar kredit (Bank Mandiri) mulai dari kredit korporasi, kredit ritel, kredit mikro, kredit konsumsi (KPR dan Non KPR ).

Tabel 1

Suku Bunga Dasar Kredit PT.Bank Mandiri (31 Januari 2017)

\begin{tabular}{ccccc}
\hline \multicolumn{5}{c}{ Suku Bunga Dasar Kredit } \\
\hline \multirow{2}{*}{ Kredit Korporasi } & Kredit Ritel & Kredit Mikro & \multicolumn{2}{c}{ Kredit Konsumsi } \\
& & & KPR & Non KPR \\
S.95\% & $9.95 \%$ & $18.75 \%$ & $10.25 \%$ & $12.25 \%$ \\
\hline Sumber : http://www.bankmandiri.co.id/
\end{tabular}

Berdasarkan tabel diatas dapat di lihat bahwa suku bunga bank mandiri $10,25 \%$ per tahunnya dan untuk kredit ritel 9,95\% per tahunnya. Berdasarkan kenyataannya dilapang bunga kredit perbankan rata-rata $10 \%$ sampai $12 \%$ pertahunnya, namun ada sebagian besar masyarakat juga sedikit malas menoleh akan penawaran kredit oleh perbankan ,hal ini biasanya disebabkan karena aturan administrasi yang dianggap cukup rumit oleh calon nasabah. Masyarakat Indonesia sebenarnya banyak yang membutuhkan suntikan dana segar atau pinjaman demi keberlangsungan usahanya akan tetapi banyak dari mereka yang terjerat oleh Bank Titil, kebanyakan masyarakat yang terjerat bank Titil adalah masyarakat yang memiliki usaha kecil misalkan toko peracangan, pedagang kaki lima bahkan masyarakat yang menjadikan uang pinjamanya tersebut hanya untuk menutupi kebutuhan dasar saja yaitu sandang dan pangan.

Bank Titil bisa diartikan sebagai kegiatan usaha masyarakat baik individu ataupun kelompok dalam bidang keuangan namun tidak berbadan hukum seperti bank-bank konvensional pada umumnya, kegiatan usahanya menyerupai perbankan dalam menawarkan jasa kredit kepada masyarakat namun prosedural administrasinya lebih di permudah. Banyak para masyarakat yang terjerat Bank Titil dan menjadi ketergantungan,setelah lunas mereka akan memakai jasa Bank Titil ini lagi bahkan akan berkelanjutan serta mereferensikannya kepada orang lain. Ketergantungan ini disebabkan karena adanya kemudahan prosedur, kecepatan realisasi pinjaman,tanpa agunan dan tidak ada sanksi bila tidak bisa mengangsur pembayarannya. Bank Titil mimiliki penamaan yang berbeda di setiap daerah, di Jawa Tengah disebut Bank Plecit ,di Jawa Timur disebut Bank Titil dan di beberapa daerah lain di nusantara ini menyebutnya dengan Bank Keliling. Tingkat suku bunga yang dikenakan Bank Keliling kepada nasabahnya beraneka ragam antar daerah berbeda akan tetapi kisaran suku bunganya antara $10 \%$ sampai dengan $25 \%$ per bulannya yang apabila kita hitung dengan suku bunga sebesar itu maka dalam satu tahun bunga dari Bank Titil ini mencapai ( $25 \% \times 12=300 \%$ ), dengan bunga $300 \%$ pertahunnya tentu sangat jauh dengan 
suku bunga perbankan resmi yang kisarannya hanya 10\% sampai dengan $12 \%$ pertahunnya.

Pelayanan jasa sejenis perbankan pada dasarnya memerlukan pelayanan yang baik bagi nasabah atau customernya, dengan pelayanan yang baik akan menciptakan kepuasan dan kepuasan yang dirasakan oleh nasabah akan menghasilkan sebuah loyalitas dimana dengan loyalitas tersebut nasabah dapat mengulang pemakaian jasa itu kembali bahkan mereferensikannya kepada orang lain. Menurut Oliver dalam (Kotler, 2009, p. 138) mendefinisikan kesetiaan sebagai komitmen yang dimiliki secara mendalam untuk membeli atau mendukung produk atau layanan yang lebih disukai di masa depan meskipun pengaruh situasi dan upaya pemasaran memiliki potensi untuk menyebabkan pelanggan beralih. Parasuraman dalam (Tjiptono, 2011, p. 198) menyebutkan bahwa dimensi kualitas terdiri dari lima faktor, yaitu: (1) Realibility; yaitu kemampuan untuk memberikan jasa dengan segera dan memuaskan; (2) Responsiveness; yaitu kemampuan untuk memberikan jasa dengan tanggap; (3) Assurance; yaitu kemampuan, kesopanan, dan sifat dapat dipercaya yang dimiliki oleh para staf, bebas dari bahaya, risiko dan keragu-raguan; (4) Emphaty; yaitu kemudahan dalam melakukan hubungan komunikasi yang baik dan memahami kebutuhan pelanggan; (5) Tangibles; yaitu fasilitas fisik, perlengkapan pegawai dan sarana komunikasi. Untuk meningkatkan kualitas layanan diperlukan pengetahuan strategik dalam bisnis (business strategy) (Badri, 2012) dalam penelitiannya yang berjudul Implikasi Operasional Bank Keliling Terhadap Eksistensi Koperasi Pengusaha Batik Tembayat Kecamatan Bayat Klaten ( studi empirik dalam mekanisme penyaluran kredit) menyimpulkan bahwa keberadaan bank keliling yang memberikan pelayanan yang sangat baik perlu dicontoh oleh koperasi misalnya karena dapat membantu masyarakat untuk mendapatkan dana segar saat terdesak, namun terkait bunga yang sangat besar dari bank keliling maka masyarkat perlu memikirkannya matang-matang sebelum menggunakan jasa bank keliling ini. Keberadaan Bank Titil yang pada tampilan luarnya terlihat membantu masyarakat yang sedang membutuhkan dana segar sebenarnya bila dinilai dari tampilan dalamnya maka Bank Titil ini sebenarnya dapat menyengsarakan nasabahnya. Menjamurnya Bank Titil di Kecamatan Sukorambi Kabupaten Jember merupakan fenomena perekonomian yang menurut kami perlu diteliti karena pada dasarnya penawaran kredit yang dilakukan oleh bank konvensional seperti BCA, Mandiri, BRI dan lain sebagainya sudah banyak akan tetapi masyarakat menengah ke bawah justru lebih tertarik dengan penawaran jasa oleh Bank Titil.

Adapun rumusan masalah dalam penelitian ini adalah; apakah kualitas pelayanan yang terdiri dari Reliability, Responsiveness, Assurance, Emphaty dan Tangibles mempunyai pengaruh secara parsial dan simultan terhadap keputusan nasabah untuk menggunakan jasa Bank Titil di Kecamatan Sukorambi? Sedangkan tujuannya adalah untuk mengetahui pengaruh secara parsial dan simultan kualitas pelayanan yang terdiri dari Reliability, Responsiveness, Assurance, Emphaty dan Tangibles terhadap keputusan nasabah untuk menggunakan jasa Bank Titil di Kecamatan Sukorambi.

\section{B. KAJIAN PUSTAKA}


Kualitas layanan pada dasarnya merupakan bagian penting dalam pemasaran karena pelayanan yang dilakukan dengan sepenuh hati demi penyampaian nilai produk ataupun jasa akan menjadi kepuasan tersendiri bagi pelanggan atau konsumennya. Kualitas sendiri dapat diartikan sebagai baik buruknya sesuatu yang apabila dihubungkan dengan kualitas layanan merupakan suatu kemampuan sebuah produk untuk memenuhi harapan pelanggannya. Dengan harapan pelanggan yang tercapai maka terjadilah kepuasan pada pelanggan, kepuasan diartikan sebagai keadaan psikis yang menyenangkan sebagai akibat terpenuhinya kebutuhan secara memadai. (Tjiptono, 2011) mendefinisikan kualitas jasa sebagai ukuran seberapa bagus tingkat layanan yang diberikan mampu sesuai dengan ekspektasi pelanggan. Dengan demikian pemenuhan kebutuhan dan keinginan pelanggan merupakan hal penting yang harus dilaksanakan oleh penyedia layanan jasa, begitu pula dalam ketepatan penyampaian jasa juga diperlukan demi mengimbangi harapan pelanggan.

\section{METODE PENELITIAN}

Jenis penelitian yang dilakukan adalah Penelitian Kausal. Penelitian kausal adalah tipe konklusif yang bertujuan untuk menentukan penyebab dan efek dari suatu penelitian (Hasibuan, 2007). Dalam penelitian ini menentukan hubungan variabel kualitas layanan dengan keputusan pelanggan untuk menggunakan layanan Titil Bank di Kabupaten Sukorambi. Pendekatan yang digunakan adalah pendekatan kuantitatif. Dalam penelitian pendekatan kuantitatif, data yang dibutuhkan adalah data dalam bentuk angka yang diwakili oleh angka (Sarwono, 2012). Penelitian ini dilakukan di Kecamatan Sukorambi Jember yang meliputi 3 Desa yaitu Desa Sukorambi, Desa Karangpring dan Desa Kelungkung. Teknik pengumpulan data adalah dengan mengamati, mewawancarai dan menyebarkan kuesioner. Populasi adalah sekelompok orang, peristiwa, atau segala sesuatu yang memiliki karakteristik tertentu (Nur Indriantoro dan Bambang Supomo, 2011). Sampel adalah bagian dari jumlah dan karakteristik populasi. Populasi dalam penelitian ini adalah semua pelanggan Bank Titil yang berlokasi di tiga desa di Kabupaten Sukorambi yang meliputi: Desa Sukorambi, Klunggung dan Karangpring. Sampel yang akan digunakan dalam penelitian ini adalah 30 nasabah Bank Titil yang tersebar merata di 3 desa di wilayah Kabupaten Sukorambi Jember.

Responden yang dimaksud adalah pelanggan Bank Titil di Kabupaten Sukorambi. Pengambilan sampel dalam penelitian ini menggunakan teknik sampling aksidental atau accidental sampling, yaitu siapa saja yang secara tidak sengaja bertemu dengan peneliti dapat digunakan sebagai sampel (Sarwono, 2012). Pengumpulan data dilakukan ketika bertemu pelanggan yang masih aktif menggunakan layanan Titil Bank di Kabupaten Sukorambi. Alat yang digunakan untuk mendapatkan data primer adalah kuesioner. Metode pengumpulan data primer dilakukan dengan menggunakan kuesioner. Sedangkan pengumpulan data sekunder diperoleh dari buku-buku yang berkaitan dengan penelitian.

Pengukuran data dalam hal ini menggunakan 5 tingkat (skala Likert) Sangat Tidak Setuju (STS) diberi bobot 1, Tidak Setuju (TS) diberi bobot 2, Netral (N) diberi bobot 3, Setuju (S) diberi bobot 4, Setuju Sekali (SS) diberi 
bobot 5 .

Variabel bebas merupakan stimulus atau variabel yang mempengaruhi variabel lain atau variabel yang variabelnya diukur, dimanipulasi atau dipilih untuk menentukan hubungannya dengan suatu gejala yang diobservasi. Dalam hal ini yang menjadi variabel bebas adalah : Reliability $\left(\mathrm{X}_{1}\right)$, Responsiveness $\left(\mathrm{X}_{2}\right)$, Assurance $\left(\mathrm{X}_{3}\right)$, Emphaty $\left(\mathrm{X}_{4}\right)$, Tangibles $\left(\mathrm{X}_{5}\right)$. Variabel terikat adalah variabel yang memberikan reaksi/ respons jika dihubungkan dengan variabel bebas atau variabel yang variabelnya diamati dan diukur untuk menentukan pengaruh yang disebabkan oleh variabel bebas. Dalam hal ini yang menjadi variabel terikat adalah keputusan nasabah (Y).

Uji Analisis data meliputi uji validitas yang menurut (Ghozali, 2001) uji validitas (uji kesahihan) adalah suatu alat yang digunakan untuk mengukur sah atau valid tidaknya suatu kuesioner. Uji Reliabilitas menurut (Ghozali, 2001) adalah alat ukur untuk mengukur kuesioner yang merupakan indikator variabel konstruk. Cara menghitung tingkat keandalan suatu data yaitu dengan menggunakan rumus Cronbach Alpha. Modus dugunakan untuk melihat nilai yang paling sering muncul atau yang frekuensinya paling tinggi dari jawaban responden. Regresi digunakan untuk mengukur besarnya pengaruh variabel bebas terhadap variabel tergantung dan memprediksi variabel tergantung dengan menggunakan variabel bebas (Sarwono, 2012). Pengujian hipotesis dilakukan dengan uji t dan uji f dengan penjelasan sebagai berikut (Riduan, 2013). Uji t digunakan untuk mengetahui kebenaran hipotesis dari masing-masing koefisien regresi antara variabel-variabel kualitas pelayanan terhadap keputusan nasabah dalam menggunakan jasa Bank Titil di Kecamatan Sukorambi. Prosedur pengujian adalah sebagi berikut ini. Uji F bertujuan untuk mengetahui apakah variabel bebas tersebut mempengaruhi variabel terikat. Dalam hal ini, uji F digunakan untuk menguji pengaruh kualitas pelayanan terhadap keputusan dalam menggunakan jasa Bank Titil di Kecamatan Sukorambi.

\section{HASIL DAN PEMBAHASAN}

Berdasarkan penelitian yang telah dilakukan dengan penyebaran kuisioner kepada masyarakat pengguna jasa layanan Bank Titil di 3 Desa di Kecamatan Sukorambi Jember meliputi Desa Sukorambi, Karangpring dan Klungkung dengan variabel independen meliputi Tangibles $\left(\mathrm{X}_{1}\right)$, Reliability $\left(\mathrm{X}_{2}\right)$, Responsiveness $\left(\mathrm{X}_{3}\right)$, Assurance $\left(\mathrm{X}_{4}\right)$, Emphaty $\left(\mathrm{X}_{5}\right)$, dan variabel dependen $\mathrm{Y}$ (Keputusan) dalam menggunakan jasa layanan Bank Titil. Penyebaran kuisioner dilaksanakan pada tanggal 5 Juli 2017 sampai dengan 8 Juli 2018 kepada 30 responden, untuk lebih jelasnya berikut disajikan total skor dari masing- masing variabel yang terdapat dalam kuisioner seperti pada tabel di bawah ini. 


\section{Tabel 2}

Total Skor Dari Tiap-Tiap Varibel

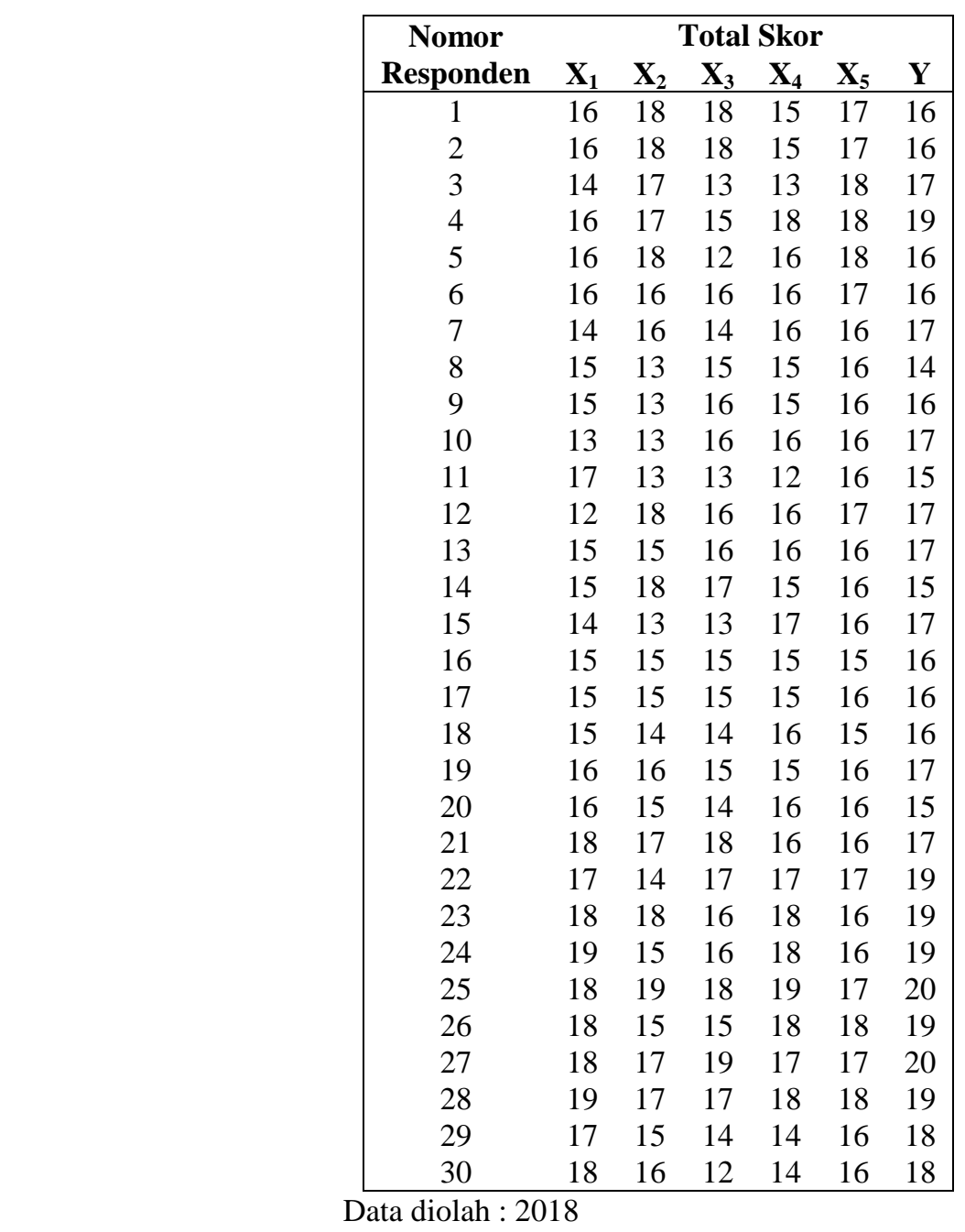

Uji Validitas

Tabel 3

Uji Validitas

Item-Total Statistics

\begin{tabular}{lccccc}
\hline & $\begin{array}{c}\text { Scale } \\
\text { Mean if } \\
\text { Item } \\
\text { Deleted }\end{array}$ & $\begin{array}{c}\text { Scale } \\
\text { Variance if } \\
\text { Item Deleted }\end{array}$ & $\begin{array}{c}\text { Corrected } \\
\text { Item-Total } \\
\text { Correlation }\end{array}$ & $\begin{array}{c}\text { Squared } \\
\text { Multiple } \\
\text { Correlation }\end{array}$ & $\begin{array}{c}\text { Cronbach's } \\
\text { Alpha if Item } \\
\text { Deleted }\end{array}$ \\
\hline Tangibles & 80,73 & 29,582 &, 450 &, 310 &, 721 \\
Reliability & 80,97 & 29,206 &, 439 &, 338 &, 726 \\
Responsiveness & 81,33 & 29,057 &, 438 &, 275 &, 727 \\
Assurance & 80,87 & 28,740 &, 587 &, 496 &, 681 \\
Emphaty & 80,27 & 36,133 &, 420 &, 318 &, 736 \\
Keputusan & 79,67 & 27,747 &, 657 &, 585 &, 661 \\
\hline Data
\end{tabular}

Data diolah : 2018 
Setiap nilai pada kolom Corrected Item Total Correlation ini dibandingkan dengan nilai $\mathrm{r}$ pada tabel $\mathrm{r}$ dengan derajat bebas $\mathrm{n}-2$ dimana $\mathrm{n}$ adalah jumlah responden dan dalam penelitan ini ada 28 responden sehingga nilai yang digunakan dalam kasus ini adalah tabel $\mathrm{r}$ dengan derajat bebas 28 dan diperoleh nilai 0,361. Pernyataan valid adalah yang mempunyai Corrected Item-Total Correlation di atas nilai $\mathrm{r}_{\text {tabel }}\left(\mathrm{r}_{\text {hitung }}>\mathrm{r}_{\text {tabel }}\right)$. Dalam penelitian ini dapat disimpulkan bahwa item kuisioner yang sudah diisi oleh responden adalah valid. Adapun nilai dari $r$ hitung dari Tangibles $\left(\mathrm{X}_{1}\right)>$ dari pada nilai $r$ tabel $(0,450>$ $0,361)$, nilai $\mathrm{r}_{\text {hitung }}$ Reliability $\left(\mathrm{X}_{2}\right)>$ dari pada nilai $\mathrm{r}_{\text {tabel }}(0,439>0,361)$, nilai $\mathrm{r}_{\text {hitung }}$ Responsiveness $\left(\mathrm{X}_{3}\right)>$ dari pada nilai $\mathrm{r}_{\text {tabel }}(0,438>0,361)$, nilai $\mathrm{r}_{\text {hitung }}$ Assurance $\left(\mathrm{X}_{4}\right)>$ dari pada nilai $\mathrm{r}_{\text {tabel }}(0,587>0,361)$, nilai $\mathrm{r}_{\text {hitung }}$ Emphaty $\left(\mathrm{X}_{5}\right)>$ dari pada nilai $r_{\text {tabel }}(0,420>0,361)$ dan nilai $r_{\text {hitung }}$ keputusan menggunakan jasa layanan Bank Titil $(Y)>$ dari pada nilai $r_{\text {tabel }}(0,657>0,361)$.

\section{Uji Reliabilitas}

\section{Tabel 4}

Uji Reliabilitas

Reliability Statistics

\begin{tabular}{rcrr}
\hline Cronbach's Alpha & $\begin{array}{c}\text { Cronbach's Alpha } \\
\text { Based on Standardized Items }\end{array}$ & N of Items \\
\hline, 746 & &, 759 & 6 \\
\hline & Data Diolah : 2018 &
\end{tabular}

Nilai Cronbach Alpha pada penelitian ini akan digunakan nilai 0.60 dengan asumsi bahwa daftar pertanyaan yang diuji akan dikatakan reliabel bila nilai Cronbach Alpha $\geq 0.60$ (Nunally,1996 dalam Imam Ghozali, 2011). Syarat suatu alat ukur menunjukkan kehandalan yang semakin tinggi adalah apabila koefisien reliabilitas $(\alpha)$ yang mendekati angka satu. Apabila koefisien alpha $(\alpha)$ lebih besar dari 0.60 maka alat ukur dianggap handal atau terdapat internal consistency Reliability dan sebaliknya bila alpha lebih kecil dari 0.60 maka dianggap kurang handal atau tidak terdapat internal consistency Reliability. Dalam penelitan ini menunjukkan bahwa pada uji reliabilitas di dapat nilai cronbach 's alpha sebesar 0,746 yang artinya lebih besar dari $0,60(0,746>0,60)$ sehingga dapat disimpulkan bahwa daftar pertanyaan yang diuji dalam penelitian ini adalah reliabel.

\section{Modus}

Modus digunakan untuk melihat nilai yang paling sering muncul atau yang frekuensinya paling tinggi dari jawaban responden atas kuesioner mengenai pengaruh Tangibles $\left(\mathrm{X}_{1}\right)$, Reliability $\left(\mathrm{X}_{2}\right)$, Responsiveness $\left(\mathrm{X}_{3}\right)$, Assurance $\left(\mathrm{X}_{4}\right)$, Emphaty $\left(\mathrm{X}_{5}\right)$ terhadap keputusan nasabah dalam menggunakan jasa Bank Titil di Kecamatan Sukorambi. Dapat dijelaskan nilai yang paling sering muncul pada $\mathrm{X}_{1}$ adalah 15,pada $\mathrm{X}_{2} 15$ dan pada $\mathrm{X}_{3}, \mathrm{X}_{4}, \mathrm{X}_{5}$ dan $\mathrm{Y}$ adalah 16. 


\section{Analisis Regresi Linier Berganda}

Dari hasil analisis regresi linier berganda dapat dijelaskan sebagai berikut: Matrik korelasi antara variabel Tangibles $\left(\mathrm{X}_{1}\right)$ dengan keputusan menggunakan jasa Bank Titil (Y) diperoleh $\mathrm{r}=0,546$ dengan probalitas $=0,001<0,10$ yang berarti bahwa ada hubungan atau korelasi yang signifikan antara Tangibles $\left(\mathrm{X}_{1}\right)$ dengan keputusan menggunakan jasa Bank Titil (Y). Matrik korelasi antara variabel Reliability $\left(\mathrm{X}_{2}\right)$ dengan keputusan menggunakan jasa Bank Titil (Y) diperoleh $\mathrm{r}=0,305$ dengan probalitas $=0,051<0,10$ yang berarti bahwa ada hubungan atau korelasi yang signifikan antara Reliability $\left(\mathrm{X}_{2}\right)$ dengan keputusan menggunakan jasa Bank Titil (Y). Matrik korelasi antara variabel Responsiveness $\left(\mathrm{X}_{3}\right)$ dengan keputusan menggunakan jasa Bank Titil $(\mathrm{Y})$ diperoleh $\mathrm{r}=0,302$ dengan probalitas $=0,052<0,10$ yang berarti bahwa ada hubungan atau korelasi yang signifikan antara Responsiveness $\left(\mathrm{X}_{3}\right)$ dengan keputusan menggunakan jasa Bank Titil (Y). Matrik korelasi antara variabel Assurance $\left(\mathrm{X}_{4}\right)$ dengan keputusan menggunakan jasa Bank Titil (Y) diperoleh $r=0,664$ dengan probalitas $=0,000<$ 0,10 yang berarti bahwa ada hubungan atau korelasi yang signifikan antara Assurance $\left(\mathrm{X}_{4}\right)$ dengan keputusan menggunakan jasa Bank Titil (Y). Matrik korelasi antara variabel Emphaty $\left(\mathrm{X}_{5}\right)$ dengan keputusan menggunakan jasa Bank Titil (Y) diperoleh $r=0,392$ dengan probalitas $=0,16<0,10$ yang berarti bahwa ada hubungan atau korelasi yang signifikan antara Emphaty $\left(\mathrm{X}_{5}\right)$ dengan keputusan menggunakan jasa Bank Titil (Y).

\section{Analisis Koefisien Determinasi $\left(\mathbf{R}^{2}\right)$}

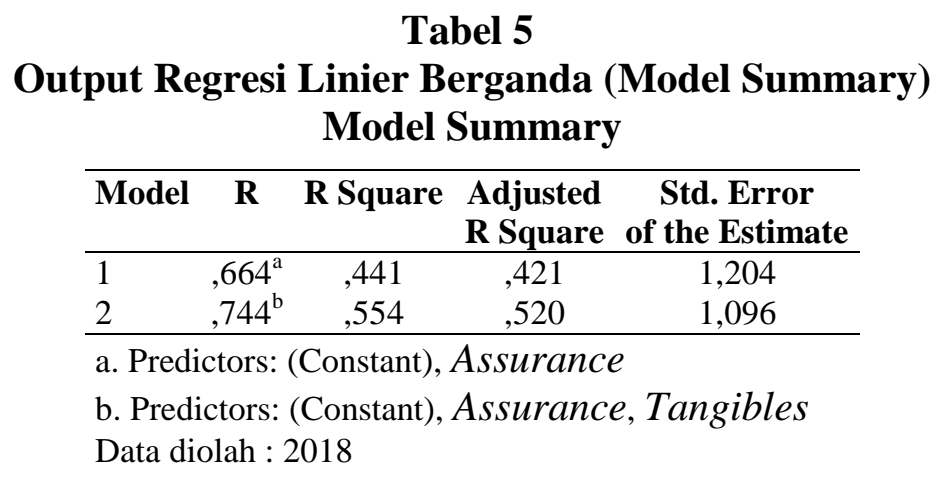

Pada tabel model summary ini dapat dijelaskan untuk model 1 menjelaskan besarnya nilai korelasi atau hubungan $(\mathrm{R})$ Assurance $\left(\mathrm{X}_{4}\right)$ dengan keputusan menggunakan jasa Bank Titil (Y) yaitu sebesar 0,664 dan penjelasan besarnya prosentase pengaruh variabel Assurance terhadap keputusan mengguakan jasa Bank Titil yang disebut koefisien determinasi yang merupakan hasil dari pengukuran R. Dari output tersebut diperoleh koefisien determinasi $\left(R^{2}\right)$ pada model 1 sebesar 0,441 yang dapat dapat diartikan bahwa pengaruh variabel bebas Assurance terhadap variabel terikat keputusan menggunakan jasa Bank Titil adalah sebesar $44,1 \%$. Selanjutnya dapat dijelaskan bahwa prosentase pengaruh Tangibles $\left(\mathrm{X}_{1}\right)$ terhadap keputusan menggunakan jasa Bank Titil adalah 55,4 \% $44,1 \%=11,3 \%$. 


\section{Uji t}

\section{Tabel 6}

Output Regresi Linier Berganda (Coefficients ${ }^{\mathrm{a}}$ )

\begin{tabular}{lcccccc}
\hline Model & \multicolumn{3}{c}{ Coefficients $^{\mathbf{a}}$} & & & Unstandardized \\
Coefficients & Standardized & t & Sig. \\
& B & Std. Error & Befficients \\
Beta & & & \\
\hline (Constant) &,- 992 & 4,353 & &,- 228 &, 822 \\
Tangibles &, 305 &, 129 &, 337 & 2,366 &, 026 \\
Reliability &, 027 &, 140 &, 031 &, 190 &, 851 \\
1 Responsiveness &,- 018 &, 132 &,- 021 &,- 134 &, 895 \\
Assurance &, 498 &, 155 &, 498 & 3,215 &, 004 \\
Emphaty &, 311 &, 286 &, 169 & 1,088 &, 287 \\
\hline
\end{tabular}

a. Dependent Variable: Keputusan

Data diolah: 2018

Berdasarkan tabel Coefficients ${ }^{\mathrm{a}}$ nilai probabilitas signifikansi maka variabel Tangibles $\left(\mathrm{X}_{1}\right)$ dan Assurance $\left(\mathrm{X}_{4}\right)$ signifikansi 0,026 dan 0,004 yang apabila diterjemahkan menjadi 0,026 dan $0,004<0,05$ yang artinya ada pengaruh yang signifikan variabel Tangibles $\left(\mathrm{X}_{1}\right)$ dan Assurance $\left(\mathrm{X}_{4}\right)$ terhadap keputusan nasabah dalam menggunakan Jasa Bank Titil, sedangakan untuk variabel Reliability $\left(\mathrm{X}_{2}\right)$ dengan nilai signifikansi 0,851 Responsiveness $\left(\mathrm{X}_{3}\right)$ dengan nilai signifikansi 0,895, dan Emphaty $\left(\mathrm{X}_{5}\right)$ dengan nilai siginifikansi 0,287 tidak berpengaruh secara signifikan terhadap keputusan masyarakat dalam menggunakan jasa Bank Titil karena nilai signifikansi 3 variabel ini lebih besar dari $\alpha_{(0,05)}$. Setelah membandingkan nilai signifikansi dengan tingkat kepercayaan yang dipilih yakni 0,05 maka akan dicoba akan dibandingkan antara hasil dari tabel dan $t_{\text {hitung, }}$, adapun nilai dari $t_{\text {tabel }}$ dari penelitian ini $\mathrm{df}=\mathrm{n}-1(\mathrm{df}=30-1=29)$ nilai $\mathrm{t}_{\text {tabel }}$ adalah 2,04523. Nilai $\mathrm{t}_{\text {hitung }}$ dari variabel Tangibles $\left(\mathrm{X}_{1}\right)$ dan Assurance $\left(\mathrm{X}_{4}\right)$ sebesar 2,366 dan 3,215 $>\mathrm{t}_{\text {tabel }} 2,04523$ artinya ada pengaruh yang signifikan variabel Tangibles $\left(\mathrm{X}_{1}\right)$ dan Assurance $\left(\mathrm{X}_{4}\right)$ terhadap keputusan nasabah dalam menggunakan Jasa Bank Titil, sedangkan variabel Reliability $\left(\mathrm{X}_{2}\right)$, Responsiveness $\left(\mathrm{X}_{3}\right)$ dan Emphaty $\left(\mathrm{X}_{5}\right)$ dengan nilai $\mathrm{t}_{\text {hitung }}$ 0,190; -0,134 dan 1,008 $<\mathrm{t}_{\text {tabel }} 2,04523$ yang artinya variabel $\mathrm{X}_{2}, \mathrm{X}_{4}$ dan $\mathrm{X}_{5}$ tidak berpengaruh secara signifikan terhadap keputusan nasabah dalam menggunakan Jasa Bank Titil.

Variabel Reliability $\left(\mathrm{X}_{2}\right)$ (kehandalan) dapat diartikan kemampuan untuk menampilkan pelayanan yang dijanjikan dengan terpercaya dan akurat, dari hasil uji t ini menunjukkan tidak berpengaruh signifikan terhadap keputusan nasabah dalam menggunakan jasa Bank Titil di Kecamatan Sukorambi, hal ini bisa dijelaskan secara implementasinya di lapang banyak para nasabah yang kecewa atas pelayanan dalam permohonan peminjaman yang tidak responsif, nasabah kecewa saat ingin meminjam kembali dipersulit oleh petugas Bank Titil, petugas beralasan bahwa nasabah sering telat dalam membayar cicilannya. Variabel Responsiveness $\left(\mathrm{X}_{3}\right)$ yaitu kerelaan melayani berkaitan dengan kemauan karyawan untuk membantu nasabah dengan cepat dan mengatasi keluhan yang diajukan nasabah, dari hasil uji $t$ ini menunjukkan tidak berpengaruh signifikan terhadap keputusan nasabah dalam menggunakan jasa 
Bank Titil di Kecamatan Sukorambi, hal ini bisa dijelaskan secara implementasinya di lapang banyak para nasabah mengemukakan bahwa petugas lapang Bank Titil tidak menanggapi secara serius keluhan dari nasabah, nasabah beranggapan bahwa Bank Titil hanya pencari keuntungan yang rakus, jika mereka nasabah rajin menyicil maka mereka betul-betul diperhatikan oleh petugas lapang Bank Titil,jika sebaliknya pasti mereka tidak di hiraukan bahkan di persulit untuk melakukan peminjaman ulang meskipun mereka nasabah telah melunasinya meskipun telat. Variabel Emphaty $\left(\mathrm{X}_{5}\right)$ merupakan kesediaan karyawan dan pengelola untuk lebih peduli dengan memberikan pemahaman dan perhatian kepada nasabah dari hasil uji t ini menunjukkan tidak berpengaruh signifikan terhadap keputusan nasabah dalam menggunakan jasa Bank Titil di Kecamatan Sukorambi, hal ini bisa dijelaskan secara implementasinya di lapang banyak para nasabah mengemukakan bahwa petugas lapang Bank Titil hanya memberikan perhatian yang lebih secara individu kepada nasabah yang lancar dalam membayar cicilannya.

Uji F

Tabel 7

ANOVA $^{a}$

ANOVA $^{\mathrm{a}}$

\begin{tabular}{|c|c|c|c|c|c|c|}
\hline & del & Sum of Squares & df & Mean Square & $\mathbf{F}$ & Sig. \\
\hline \multirow{3}{*}{1} & Regression & 42,496 & 5 & 8,499 & 6,753 &, $000^{\mathrm{b}}$ \\
\hline & Residual & 30,204 & 24 & 1,259 & & \\
\hline & Total & 72,700 & 29 & & & \\
\hline
\end{tabular}

a. Dependent Variable: Keputusan

b. Predictors: (Constant), Emphaty, Responsiveness, Tangibles, Assurance, Reliability

Data Diolah : 2018

Menentukan df pada $\mathrm{f}_{\text {tabel }}$ dilakukan dengan cara $\mathrm{df}_{1}=\mathrm{k}-1$ selanjutnya $\mathrm{df}_{2}=$ $\mathrm{n}-k$ dimana $k$ adalah jumlah variabel (bebas + terikat) dan $\mathrm{n}$ adalah jumlah observasi/sampel pembentuk regresi. Maka nilai $\mathrm{f}_{\text {tabel }}$ dalam penelitian ini dapat ditentukan sebagai berikut $\mathrm{df}_{1}=\mathrm{k}-1=6-1=5$ sedangkan $\mathrm{df}_{2}=\mathrm{n}-\mathrm{k}=30-6=$

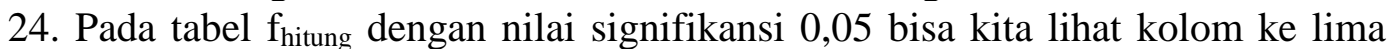
dan baris ke 26 maka nilai tersebut adalah nilai dari $\mathrm{f}_{\text {hitung }}$ sebesar 2,59. Dari hasil Anova di dapat $f_{\text {hitung }}>f_{\text {tabel }}$ yaitu 6,753 $>2,59$ yang artinya secara simultan atau bersama-sama variabel $\mathrm{X}_{1}, \mathrm{X}_{2}, \mathrm{X}_{3}, \mathrm{X}_{4}$ dan $\mathrm{X}_{5}$ berpengaruh secara signifikan terhadap keputusan masyarakat dalam menggunakan Jasa Bank Titil di Kecamatan Sukorambi.

\section{E. SIMPULAN}

Berdasarkan tabel Coefficients ${ }^{a}$ nilai probabilitas signifikansi maka variabel Tangibles $\left(\mathrm{X}_{1}\right)$ dan Assurance $\left(\mathrm{X}_{4}\right)$ berpengaruh signifikan terhadap keputusan nasabah dalam menggunakan Jasa Bank Titil. Untuk variabel Reliability $\left(\mathrm{X}_{2}\right)$ Responsiveness $\left(\mathrm{X}_{3}\right)$ dan Emphaty $\left(\mathrm{X}_{5}\right)$ tidak berpengaruh secara signifikan terhadap keputusan masyarakat dalam menggunakan jasa Bank Titil.

Variabel Reliability $\left(\mathrm{X}_{2}\right)$ (kehandalan), dari hasil uji t ini menunjukkan tidak berpengaruh signifikan terhadap keputusan nasabah dalam menggunakan jasa Bank Titil di Kecamatan Sukorambi, hal ini bisa dijelaskan secara 
implementasinya di lapang banyak para nasabah yang kecewa atas pelayanan dalam permohonan peminjaman yang tidak responsif, nasabah kecewa saat ingin meminjam kembali dipersulit oleh petugas Bank Titil, petugas beralasan bahwa nasabah sering telat dalam membayar cicilannya. Variabel Responsiveness $\left(\mathrm{X}_{3}\right)$, dari hasil uji t ini menunjukkan tidak berpengaruh signifikan terhadap keputusan nasabah dalam menggunakan jasa Bank Titil di Kecamatan Sukorambi, hal ini bisa dijelaskan secara implementasinya di lapangan banyak para nasabah mengemukakan bahwa petugas lapang Bank Titil tidak menanggapi secara serius keluhan dari nasabah, nasabah beranggapan bahwa Bank Titil hanya pencari keuntungan yang rakus, jika mereka nasabah rajin menyicil maka mereka betulbetul diperhatikan oleh petugas lapang Bank Titil, jika sebaliknya pasti mereka tidak di hiraukan bahkan di persulit untuk melakukan peminjaman ulang meskipun mereka nasabah telah melunasinya meskipun telat. Variabel Emphaty $\left(\mathrm{X}_{5}\right)$, dari hasil uji t ini menunjukkan tidak berpengaruh signifikan terhadap keputusan nasabah dalam menggunakan jasa Bank Titil di Kecamatan Sukorambi, hal ini bisa dijelaskan secara implementasinya di lapang banyak para nasabah mengemukakan bahwa petugas lapang Bank Titil hanya memberikan perhatian yang lebih secara individu kepada nasabah yang lancar dalam membayar cicilannya. 


\section{DAFTAR PUSTAKA}

Badri, S. (2012). Implikasi Operasional Bank Keliling Terhadap Eksistensi Koperasi Pengusaha Batik Tembayat Kecamatan Bayat-Klaten. Jurnal Orasi Bisnis, 27-36.

Bank Mandiri. (2017, Februari 12). bankmandiri. Diambil kembali dari www.bankmandiri.co.id: http://www.bankmandiri.co.id/ resource/sbdk.asp

F Engel, J. (2010). Perilaku Konsumen Jilid 1 Edisi Terjemahan. Jakarta: Binarupa Aksara.

Ghozali, I. (2001). Aplikasi Analisis Multivariate dengan program SPSS, Edisi kedua. Semarang: Badan Penerbit Universitas Diponegoro.

Hasibuan, Z. A. (2007). Metodologi Penelitian Dalam Bidang Ilmu Komputer dan Teknologi Informasi. Depok: Fasilkom Universitas Indonesia.

Indriantoro, N. d. (2011). Metodologi Penelitian Bisnis Untuk Akuntansi \& Manajemen Cetakan Ke IV. Yogyakarta: BPFEY.

Khittah. (2010). Analisis Pengaruh Kualitas Layanan Terhadap Kepuasan Dan Loyalitas Konsumen Dalam Menggunakan Jasa Salon Kecantikan Di Kecamatan Kota Pada Kabupaten Jember. Tesis. Jember: Program Pasca Sarjana Universitas Jember.

Kotler, P. (2009). Manajemen Pemasaran Edisi 13 Jilid 1 \& 2 Edisi Terjemahan Oleh Bob Sabran. Jakarta: Erlangga.

Riduan, A. R. (2013). Cara Mudah Belajar SPSS 17.0 Dan Aplikasi Statistik Penelitian. Bandung: Alfabeta.

Sarwono, J. (2009). Statistik itu Mudah, Panduan Lengkap Mengajar. Yogyakarta: Andi Offset.

Sarwono, J. (2012). Metode Riset Skripsi Pendekatan Kuantitatif Menggunakan Prosedur SPSS. Jakarta: PT.Gramedia.

Tjiptono, F. (2011). Service, Quality \& Satisfaction Edisi 3. Yogyakarta: Andi Offset. 